\title{
Student Unrest in Public Universities in Kenya: The Nexus between Principles of Governance and Student Leadership
}

\author{
Dr. Washington Okeyo PhD \\ Deputy Vice-Chancellor and Senior Lecturer, \\ Management University of Africa, Kenya
}

Doi: 10.19044/esj.2017.v13n31p159 URL:http://dx.doi.org/10.19044/esj.2017.v13n31p159

\begin{abstract}
Student unrest has been a major problem in Kenya for the government, public universities, the community, society, and even students themselves for several decades. However, the student leaders, majority of who are undergraduates in their late teens to early twenties, lack governance and leadership skills and experience. This study focused on principles of governance and leadership among student leaders in public universities. The study was anchored on positivist research philosophy and adopted a cross sectional design. The target population was all the 35 public universities in Kenya and data was collected from 70 student chairpersons and their deputies. Data was mainly collected from primary source using structured questionnaire and analyzed using descriptive and regression analysis. The study established that student leaders exhibited both performance and accountability principles of governance albeit weakly. The study however found no significant relationship between and student leadership and governance principles of legitimacy and voice; direction; and fairness. This study thus concludes that when student leaders are articulating their fellow students' issues, the leaders are guided by responsiveness, effectiveness, efficiency, transparency, and information flow. The leaders however lack appreciation for rule of law; equity; consensus orientation and mediation; as well as long-term strategic vision for the student body. The study therefore recommends that public universities should immediately train all incumbent student leaders on leadership concepts and principles of governance. However as a long-term measure, universities should introduce curriculums on principles of governance and leadership concepts contextualized to undergraduate students' area of study.
\end{abstract}

Keywords: Governance principles, Student leadership, Student unrest, Public University 


\section{Introduction}

The world has witnessed mushrooming of universities as a result of globalization resulting from advances in technology and increased interdependence arising from flow of information, ideas and knowledge (Knight, 2008). Equally, student unrest in universities has risen proportionately and has been observed in several countries worldwide (Mwiria \& Ng'ethe, 2006). Student unrest has been defined in different ways by various authors. Ojo (1995) referred to it as student crisis and defined it as the effects caused by students as they demand their rights from university authorities. Another definition by Adeyemi (2009) portrays student unrest in terms of demonstrations by students arising from their protest to pressurize the university administration for their demands leading to destruction of lives and property. Other researchers have referred to student unrest as protests undertaken by the student community in the process of confronting university authority over their dissatisfaction with the way their issues are handled (Falua, 2004; Adeyemi, 2009). Student unrest in Kenya dates back to the 1970s when the country had only one university - the University of Nairobi (UoN). At that time, despite being only one university, very few academic years reached their full term without being closed early due to student riots.

Student unrest is an important issue to many stakeholders including the student community, the university administration, the society at large, and the government (Kiboiy, 2013). According to the study by Kiboiy (2013), unrest from students leads to premature closure of universities which makes the students spend longer time in pursuit of their academic programmes. This results in interruptions of student programmes and consequent delay in their post-education productive life. Student unrest also has a negative impact on the University plans. Universities operate based on academic calendars which assume that each cohort or student intake will stay in the university for a specified period of time. Use of various university facilities like hostels, lecture rooms, laboratories, and sports as well as lecturers and administrative staff is therefore planned with this in mind. However, when students riot which often leads to university closure, the calendar is seriously interrupted with the result that the affected university cannot admit fresh students as and when expected. For example the student riots at UoN in 1982 following a coup attempt led to the University's closure for more than 12 months from August 1982 to October 1983, creating a backlog of new student intakes. The closure seriously interrupted UoN programmes for several decades thereafter and this forced the university to introduce a "double-intake" system in 1989 by admitting two groups of qualified students at the same time (Kiai, N.d). 
Unrest of students also hurts the business and other communities operating or living around universities. Rioting students often engage in wanton destruction of businesses and property sometimes resulting even in loss of lives. Riots by UoN students always spill over into the streets of Nairobi occasioning stoning of vehicles, and breaking and looting of business premises. In 1993 riots by Moi University students which lead to closure of the university for two months, spilt over into the University neighbourhood resulting in destruction of property worth millions of shillings. Similar violent student unrests were experienced in Moi University again in 1999 and resulted in its closure for one academic year. Other universities which experienced similar riots with devastating consequences are Maseno University in 1994, University of Nairobi in 1982, Egerton University in 2014, and Moi University in 1999 (Kiboiy, 2013).

Debate on principles of governance and student leadership in public universities urging for the student body to be more involved in responsible behavior has attracted increased attention (Jaramilla \& Lazo, 2010). The quality of student leaders is of critical concern not only to the university fraternity but also to the whole society since it affects student-community relationship which may have social, economic, as well as academic impact. This has been evidenced by a series of confrontations and destruction of property by university students in Kenyan cities like Nairobi, Nakuru, Eldoret, Maseno and other cities hosting public universities (Mwiria \& Ng'ethe, 2006). Arising from the increasing need for greater responsibility and accountability in management of student affairs, most universities all over the world have decided to reform their approach to managing student affairs (Kathryn et al., 2016). The often violent student strikes and demonstrations being experienced in many universities has forced public universities to rethink the way they manage student leadership. Thus principles of governance are important factors that can lead to achievement of more effective student leadership (Magolda \& Ebben, 2006) and thus reduce student unrest in public universities in Kenya.

\section{Principles of governance}

Governance refers to broad-based structures and processes that are used to ensure a level playing field in an institution or organization (UNESCO, 2017). The main objective of governance is to ensure accountability, transparency, and responsiveness, rule of law, stability, equity, and inclusiveness as well as empowerment and broad-based participation (UNESCO, 2017). This can positively impact on the student leadership and other stakeholders when making decisions that can improve the relationship between students and the university administration. Governance also provides the rules, norms, and values of the game through 
which student affairs are managed in a transparent, responsive, participatory, and inclusive manner.

Principles of governance are a set of norms and values which together articulate how good governance should be achieved when dealing with matters concerning the society. Defining principles of governance is not only difficult but is also often controversial. UNDP (1997) developed a five item framework that is often used in literature with slight variations to represent principles of governance. The framework presents these principles, also used to operationalize governance, in five themes comprising legitimacy and voice, direction, performance, accountability, and fairness.

According to UNDP (1997), legitimacy and voice principle is achieved through participation and consensus orientation. Participation holds that voices of men and women should be included in decision making either directly or via intermediate institutions. Consensus orientation on the other hand is meant to intervene between differing interests so as to achieve a bestfor-group consensus (Graham, Amos \& Plumptre, 2003).

Direction principle entails providing strategic vision which requires leaders and the public to possess long-term but broad perspectives on good governance and human development (UNDP, 1997). This principle also requires an appreciation of cultural, historical, and social complexities based on each perspective. Another principle of governance is performance (Graham, Amos \& Plumptre, 2003). This entails responsiveness coupled with effectiveness and efficiency. The principle holds that all stakeholders should be served equally by the institutions and processes and that these should yield results which meet the set goals through optimal use of resources.

UNDP's (1997) fourth principle, accountability, basically has two arms - accountability and transparency. The arm of accountability is the process by which various interested parties including government, private sector, and civil society are accountable to the public and institutional stakeholders. It is based on whether decision is internal and external to an organization. The second arm, transparency, is built on free-uninhibited flow of information. Transparency is achieved when there is direct access by those interested to process, institutions, and information giving them the ability to monitor those processes.

The fifth and last principle in UNDP's (1997) framework is fairness which has two components - equity and rule of law. Equity is the opportunity accorded to all men and women to enable them improve or maintain their well-being. The rule of law on the other hand holds that there should be frameworks that are fair and impartially enforced, especially with regard to human rights. 


\section{Student Leadership}

Universities all over the world have embraced the concept of student leadership as a link between students and university administration for several decades. Student leadership is an important concept especially in universities with large numbers of students. Globally, student leadership has played a pivotal role in many universities for a long time. For example, radicalism within student leadership was traced to student activism in the United States of America (USA) in the 1930s. A similar situation started manifesting in Kenya in the 1970s at the University of Nairobi, then the only university in the country. At that time, student activism was associated with university professors whose teaching was thought to focus more on ideologies of communism, socialism, and anarchy (Cohen, 1993; Bosire, Chemnjor, \& Ngware, 2008). Student leadership has however continued to become more vibrant in the university fraternity in Kenya, especially following the phenomenal rise in the number of public universities now numbering 35 out a total population of 71 universities countrywide (Commission for University Education, 2017).

Student leadership in universities in Kenya, just like elsewhere in the world, is an important phenomenon which brings together the entire university student community under one distinct group. It gives the student fraternity the ability to speak with one unified voice when articulating student issues and bargaining for student rights from the university management. Student leadership is referred to differently in various universities both globally and locally. Union, government, and congress are some of the common terminologies used to refer to student leadership worldwide. Bosire, Chemnjor, and Ngware (2008:197) argue that regardless of the terminology used, student leadership is a "body that represents a student parliament that has office bearers who are elected after every academic year." The primary role of student leadership is to act as a platform or panacea which the students use as a link between them and the university management as well as to address social, political, academic, and corporate issues affecting them as a student community.

Existence of student leadership in universities in Kenya is a legal matter provided for in the Universities Act amended in 2012. According to the Act, the student leadership contributes to decision-making on students' academic and social life within the university and is therefore an integral part of university management. The Act also stresses that the student leadership must be registered as a student body and approved by the university Senate in which the body is represented during meetings especially when discussing student matters. The student leadership is thus a legal entity with its own constitution and recognized by and within the university administration and 
governance structure. Therefore, governance is a critical issue that requires attention during and after election of student leaders.

\section{University Education in Kenya}

In Kenya, university education is regulated through an Act of parliament which provides the requirements for establishment and accreditation of universities in the country. According to Kenya Law Reforms (2012), the Universities Act (2012:1870) states that "every university in Kenya shall be established by a Charter in accordance with the Act." The Act also establishes the Commission for University of Education (CUE) and gives it the sole mandate of regulating university education in the country (p. 1861). The Act however bestows the role of governance upon each university based on the structure which is clearly described within the Act itself. In this description, every university should apply for a Charter which shows its governance structure and systems among other administrative and academic obligations. However, as is standard practice worldwide, universities in Kenya follow a governance structure with the Chancellor at the apex followed by University Governing Council which is the defacto board of the university, and finally the university management headed by the Vice-Chancellor (VC).

The VC is responsible for the day to day management of administrative and academic functions of a university. The VC manages these functions through structures which differ based on size and complexity of a particular university. At minimum though, the academic function of a university is headed by a Deputy Vice-Chancellor (DVC) in charge of academics, research and student affairs, but operating with the guidance of the University Senate, and other academic organs including Deans and School Board Committees. The Senate is chaired by the VC and draws its membership from senior academics of the university with representation from the student leadership. It is the supreme organ charged with the responsibility of all academic matters of a university. The Senate formulates policies, sets academic standards, and approves programmes, curriculums, structures, and student admissions which are operationalized and implemented by Deans, School Board and other lower organs of the university. The administrative arm of the university is usually headed by a Deputy Vice-Chancellor - Finance and Administration and looks after financial and general administration matters of the university.

\section{Public Universities in Kenya}

Kenya National Law Reforms (KNLR) (2012) defines a public university as "a university maintained or assisted out of public funds." It is a university that is primarily supported through public funds administered via 
national or subnational government. Public universities are also controlled by the government especially regarding appointment of senior officers of the university. There are a total of seventy one (71) universities accredited to offer university education in Kenya (Commission for University, 2017). Out of these, thirty five (35) are public universities over half of which were commissioned within the last one to two decades. The oldest of them is the University of Nairobi (UoN) which was commissioned in 1970 alongside Makere University in Uganda and Dar es Salaam University in Tanzania from the then University of East Africa (Mbirithi, 2007). Moi University followed much later in 1984, and then Kenyatta University in 1985 before other public universities like Egerton, Jomo Kenyatta University of Agriculture and Technology, Maseno, and Masinde Muliro were established. According to University World News (2014), the total public university enrolled student population in the country in the year 2013 was estimated at 324,560 against 48,211 enrolled in private universities. This means that public university student population is over $85 \%$ of the total university student enrollment in Kenya.

Public universities in Kenya are governed in a similar manner as earlier discussed. However, unlike the private universities, the departure in public universities is that appointments of the Chancellor, UGC members, VCs and DVCs is the prerogative of the government. But Siringi and Letting (2016) argue that government controlled appointments of senior officers of public universities are informed more by ethnic and political orientations rather than meritocracy. This, they argue, is evident in public universities in Kenya where most VCs belong to ethnic communities where these universities' main campuses reside and in addition often support the government which appointed them (Munene, 2012). Thus the way public universities in Kenya are managed is often perceived to be more pro-status quo of the incumbent government and against the students' interests.

According to a study by Kiboiy (2013) on dynamics of student unrests in Kenya's higher education, the pro-government style of management is inappropriate and untenable. The approach lacks sensitivity to a student's social, economic, and academic interests. The study noted that there is serious concern about the welfare of students and that there is lack of adequate accommodation facilities resulting in students being forced to seek alternative accommodation elsewhere which is often more expensive and cumbersome. Sifuna (2010) further notes that public universities' management do not provide appropriate catering facilities with affordable meals. This forces some poor students who cannot afford them to forgo their meals. It is further noted that the lecture rooms and other academic facilities are too small and inadequate to accommodate the ever increasing student numbers. The same academic facilities that were in use when student 
populations were very small are still being used to-date despite the astronomical increase in the student numbers which has more than quadrupled. This is in addition to shortage of qualified academic staff which has forced many public universities to engage even master's degree holders and part-time lecturers to respond to increased student enrolment (Kivati, 2017).

Currently public universities are in a dire financial situation, with escalating debts arising from loans borrowed to finance infrastructure expansion (Gudo, 2014). In the recent past, many public universities engaged in rapid infrastructure expansion programmes to build or purchase towers in response to increased number of students enrolled. This has been further exacerbated by inability of the government to fund public universities' expansion. Gudo (2014) explains that, most (80\%) of government funding for public universities are used to pay emoluments leaving a meagre $20 \%$ for operations and maintenance. This inability may be attributed to the increased number of public universities and the government's high debt levels. In the last five years or so, the government has borrowed heavily to finance government infrastructural projects such as road-network expansion, standard gauge railway transport system, medical equipment and others. As a result, the government has been delaying the disbursement of loans both towards student education and university maintenance which grossly affects the smooth running of the institutions.

While increase in number of public universities has led to increased access to public education in Kenya, attention given to student issues raise concern. Educationists have argued that the steep rise in student enrollment was not accompanied with adequate expansion of both academic and other facilities (Kivati, 2017). This has adversely affected the students' living and learning environment often resulting in many student unrests frequently ending in violent conflicts in majority of public universities in Kenya.

\section{Statement of the problem}

The high rate of student enrollment has seriously constrained the ability of public universities in Kenya to provide adequate living and learning environment. Many students however are not adequately equipped with requisite governance and leadership skills and experience even though the student body is represented in university management organs. As a result, most student leaders from public universities have had challenges with university management due to lack of effective student leadership. This results in a situation where the student leadership cannot articulate well, to the university administration, issues affecting the student body in an appropriate and sober manner. As a result, there has been an escalation of student unrests leading to disruption of academic programs and destruction 
of property (Mwiria \& $\mathrm{Ng}$ 'ethe, 2006). It is for this reason that student governments need to be typically structured along various functional spheres.

According to Magolda and Ebben (2006), universities and colleges are realizing that it is important to provide meaningful and purposeful out-ofclass experience for all students. The emergence of principles of good governance is now being used elsewhere including private universities and other private entities to improve organizational performance (Kathryn et al., 2016). Although there are many advocates of effective student leadership, a lot needs to be done to find out whether student leaders require more education on governance practices and adopt them in practice. Thus there is need for solutions focused on increasing the governance and leadership capability of student leaders. The question that begs an answer is: Which governance principles are being practised by the current student leaders in public universities and what form of governance principles should public university student leaders adopt? It is with this question in mind that this study aimed to achieve its main objective which was to establish the governance principles in the current public university student leadership in Kenya and recommend appropriate actions necessary in student leadership so as to reduce frequency of student unrests.

\section{Theoretical Literature Review}

The issue of student unrest is at the heart of the society, government, public universities, and students. The astronomical rise in the number of public universities and student enrollment in Kenya has stretched the ability of the government to provide adequate funding to support public universities (Gudo, 2014). Inclusion of student leaders in the university Senate was introduced as a measure to provide students with an opportunity to articulate their views in this highest academic organ of the university. This is despite the counter position that inclusion of students in university organs is inappropriate since the students do not have the necessary governance and leadership skills and experience. These two opposing views make one wonder whether participation of student leadership in the Senate is beneficial for the university administration and the student body. This study was conducted within the purview of stewardship and agency theories. These two theories provided the theoretical grounding for factors, for and against the relationships being studied.

\section{Stewardship theory}

Stewardship theory was formulated by Block (1993) who asserted that stewardship is the choice for service. According to Sergiovanni (2000), in leadership, "Stewardship manifests in terms of teamwork in an environment embracing diversity and practising accountability and 
innovation." Effectively, stewardship comprises teamwork in which regular attendance takes place in organizational meetings. It also manifests through diverse opinions' integration and when individuals' goals accomplishment and achievement evaluation is relevant. According to Block (1993), characteristics of traditional leadership need replacement with measures of accountability, innovation, service, and empowerment. He states that stewardship starts from being willing to be accountable and goes beyond ourselves - for example to organization or community.

When one makes a choice of service above self-interest, it shows willingness for accountability without choosing to try and control the world around them (Sergiovanni, 2000). "Steward" in the reader's mind means the understanding of the role of students in representing the institution. This is a leadership role and academic officials designate it to student leaders who they think can serve the institutional interests while at the same time allow other delegates to work with them and reach sensible resolutions (Drafke \& Kossen, 2002). From the student leadership and public service perspectives, leadership can be referred to as "a relational process of people together attempting to accomplish change or make a difference to benefit the common good" (Komives, Lucas \& McMahon, 1998). Oketch (2014) adds that leadership involves the act of initiating the actions and ensuring change process starts which he describes as a function of the social state as well as personality of the individual at the center of it. This theory is most applicable for this study as it clearly provides the student leaders with a clear guideline on how to govern other students and use appropriate leadership when representing other students in university forums.

\section{Agency Theory}

Adams Smith's book titled the "Wealth of Nations" published in 1776 suggests that many of the key concepts of agency theory started emerging in the $18^{\text {th }}$ Century. However Delves and Patrick (2010) report that a separate and distinct theory on agency was authored much later by Steven A. Ross and Barry M. Mitnick in the early 1970s. Ross (1972) presented a paper titled, "The economic theory of agency: The principals' problem" to American Economic Association (Delves \& Patrick, 2010) as cited in Mawanza (2014). This was the first paper which presented "agency" as a widespread problem separate from theory of the firm. Ross' paper outlined the issue of incentive and presented a model which may be used to induce the agent towards maximizing gains produced for the principal. A year later, Mitnick (1973) came up with a theory of agency which was much more general and could possibly be applied to more diverse social contexts. Mitnick's (1973) theory listed three agency problems, which have become 
the defining dimensions of agency theory, as that of the principal, agent, and policing mechanisms and incentives.

According to Mitnick (1973) the main issue behind the principal's problem is motivating his agents to perform so as to achieve the goals set by the principal. Tools used for motivation include financial incentives, sanctions, information supply, and preferences in support of principal's goals. Agent's problems on the other hand concern how to take action in his own or principal's interest or some common in-between position when the two differ. The problem of policing mechanisms and incentives arises in situations to do with the need to limit the discretion of the agent. These may include surveillance or tasks that are specifically directed. They also include incentive systems such as rewarding the agent through compensation in form of bonuses or increased pay for being obedient to the principal.

In a public university setting, the interest of administration is to offer academic programmes within an environment conducive to learning but a reasonable cost. In line with Jensen and Meckling (1976), the main objective of a firm is to maximize its value. However, the government being the supplier of funds to run the university only gives limited amounts of money which is barely adequate for emoluments and administration costs (Gudo, 2014). Maximizing public university value is thus constrained by limited resources provided by the government and high number of students enrolled. In the process, when public universities attempt to optimize utilization of the "little" funding to stretch throughout the academic year, they disenfranchise the student body. This agitates the students whose interest is to receive quality education in an environment that is conducive to good living and learning. The students' argument is that the government should fund their university education adequately and therefore sees the university as intentionally refusing to use funds from the government efficiently towards their quality education.

The agency problem arises because the main objective of the university, which is to stretch out the funding received from the government to last the entire academic year, differs with that of the students, which is good living and quality education. Fieldings (2012), observation suggests that student leadership structures that support public university administration would have a greater impact on participating students. This study therefore argues that student unrest issue is a principal (public university) - agent (student) problem as such provisions of agency theory may be used to find solutions such as training student leaders in governance, to increase their understanding and appreciation of the management of public universities. This would lead to less destruction of property including that of the university and better maintenance of law and order. 


\section{Empirical Literature Review}

The main objective of this study was to establish the governance principles in the current public university student leadership in Kenya and recommend appropriate actions necessary to be taken so as to reduce student unrests. Governance principle was conceptualized as a multi-dimensional construct in accordance with the framework developed by UNDP (1997). This framework presents legitimacy and voice, direction, performance, accountability, and fairness as the five measures for operationalizing governance principle. This section therefore reviews empirical literature on the relationship between each dimension of governance principle and student leadership.

\section{Legitimacy and Voice principle, and Student Leadership}

The role of legitimacy and voice principle in decision making is important as it touches on the rights of all involved parties. This may be either directly or through intermediate institutions charged with that responsibility. According to Nagel (1987) participation involves a situation in a political system in which results are influenced either directly or indirectly by various players such that some movement, effort, or energy changes occur as a result in favour of participants. In agreement, CookSather (2006) advocates for a situation where the students are accorded the opportunity to participate so as to enable them exert their agency, power, and presence. In addition, student voice should adopt the shape of a pyramid and move from merely being heard, and spread to being capacitated to face challenges of leadership (Mitra, 2006). According to the research, young people are more inclined towards opportunities that enable them discuss issues that concern them. They thus yearn for chances for participation which afford them possibility of tangible results through real agency (Eckersley et al, 2007).

Mitra (2006) further demonstrates that to develop student capacity, there is need to concentrate efforts to enable youth have a share in focusing their contributions during discussions. This is likely to empower them to take lead roles in a focused manner in the process of making decisions. From this perspective, experience gained from participation gives a stronger sense of belonging to the students within the school. It also gives them a stronger feeling as learners (McInerney, 2009). Obondo (2000) also argues that the importance of decision making may arise from the diverse conflicts which are likely to manifest when power relationship is unequal. It may also be apparent since universities are considered to be democratic institutions which advocate for issues in a fair manner. For democracy to prevail, student leaders could be given more representation opportunity in the governing bodies (Walsh, 2012). The common function of student governments in the 
$21^{\text {st }}$ century is described by Fieldings (2012) as the official students' voice to institutions' administration which allows them (students) the right to be involved in the processes of making decisions of university governance.

\section{Direction principle and Student Leadership}

Direction includes long term vision, where the public and their leaders share a strategic but broad view on good governance issues and those concerning the development of human capacity while encompassing the elements of what is to be developed. In Fayol's (1949) original conceptual framework of the 14 principles of management, direction is presented as a governance role. In particular, organizations were governed by only one board, a single chief executive, and had only one strategic plan. They also had only one mission and vision. Fayol further argues that these elements comprising governance of organizations exhibited cohesion, and unity or direction across the board. Furthermore, anything over and above would likely result to confusion, waste, disorder and ineffectiveness mainly as a result of disunity.

\section{Performance principle and Student Leadership}

This principle includes responsiveness where institutional processes are targeted at serving all stakeholders. It also entails efficiency and effectiveness where results from these processes satisfy the needs arising from optimal utilization of resources. According to Holdsworth (2013), planning and organizational effectiveness are strongly correlated. Yirdaw (2016) further argues that sustainable economic development in less developed countries such as Ethiopia needs an effective and efficient education system. Among other advantages, a system that is effective and efficient is likely to improve the process of training and educating people as future workforce. It is also likely to produce future leaders as well as create an environment conducive for learning while enriching the landscape for intellectual and academic discourse (Yukl, 2009). This means that more opportunities are available to facilitate student discussions on matters affecting them and this can lead to win-win solutions and hence is very helpful.

Jaramilla and Lazo (2010) observe that in the past, student government has more effectively coordinated and ensured appropriate representation from the beginning to when the working committees are created. According to Toshalis and Nakkula (2012), effectiveness is how the needs of clients are addressed while efficiency is the process of achieving effectiveness through use of resources. In the school environment, student leadership can lead to stronger student engagement and motivation and this could enhance better academic performance in turn. In agreement, scholarly 
attention has come from organizational success while relying on the perceptions of multiple key stakeholders to measure organizational effectiveness (Jaramilla \& Lazo, 2010).

\section{Accountability principle and Student Leadership}

Jaramilla and Lazo (2010), argues that there are concerns about transparent student governments. They identify some of these as absence of governments' thrust related information as disbursement of each takes the lead. As a result, students have been empowered more and are able to keep pace with their government. This is where accountability of the leaders in an organization or association is to the public as well as to the institutional stakeholders (Gvirtz \& Minvielle, 2009). It also includes the aspect of transparency which is built on free information flow in terms of the processes within institutions through which information can be directly accessed by the interested users in adequate form and content to enable them understand and perform monitoring function as necessary. In organizational theory, the responsibility principle clearly holds that, first and foremost, subordinates take responsibility of their performance directly and, secondly, that supervisors take direct responsibility for the performance of those who work under them (Walsh, 2012).

\section{Fairness principle and Student Leadership}

Fairness includes equity and is a situation in which every human being possesses opportunities necessary for improving or maintaining their well-being. It also includes an aspect of rule of law, where legal frameworks are enforced in a fair and impartial manner, especially human rights laws. Obondo (2000) notes that there is need for fair and decentralized distribution of power and authority among all the dominant campus community groups. In his assessment of the challenges in equality in higher education in Africa, Materu (2007) observed that the phenomenon of student leadership and how it is tied to democracy have raised global interests. For example in the United States of America (USA), it has been established that since the late 1700s, student governance has consistently continued to manifest in collegiate education (May, 2009).

\section{Hypotheses for the study} follows:

The relationships depicted in this study were hypothesized as

$\mathrm{H}_{01}$ : There is no significant relationship between legitimacy and voice and student leadership

$\mathrm{H}_{02}$ : Direction principle does not have a significant influence on student leadership. 
$\mathrm{H}_{03}$ : The relationship between performance principle and student leadership is not significant. $\mathrm{H}_{04}$ : Accountability principle has no significant impact on student leadership

$\mathrm{H}_{05}$ : There is no significant relationship between fairness principle and student leadership.

\section{Methodology of the study}

This study was anchored on positivist philosophy. Five hypotheses were formulated to interrogate the perceived relationships among the variables. The study adopted cross sectional design in which data was collected at a particular point in time in the months of May and June 2017. This was a census study in which the target population was all the 35 public universities in Kenya. The target respondents were 35 student chairmen and their 35 deputies in all public universities. Data was collected from primary sources using structured questionnaire. The questionnaires contained both closed and open ended questions. The questionnaire was designed in a five point Likert scale format where 1=strongly disagree, 2=disagree, $3=$ uncertain, $4=$ agree and 5=strongly agree. Open ended questions were used in the questionnaire to collect non-quantitative data to assist in explanations. The open ended section had alternative questions for the respondents to articulate their own views for illustrating their perceptions regarding various aspects of governance and leadership. A pilot test was conducted on ten (10) non-chair or deputy student leaders to collect data for testing reliability of the instrument and validity of the contents of the questionnaire. Cronbach's alpha values for reliability tests in SPSS Version 22 using pilot test data are presented in Table 1.

Table 1: Reliability Statistics: Cronbach's Alpha ${ }^{a}$

\begin{tabular}{ccc}
\hline Variable & Croncbach's Alpha $^{\mathrm{a}}$ & No. of Items \\
\hline Legitimacy and voice & 0.584 & 6 \\
Direction & 0.700 & 8 \\
Performance & 0.853 & 8 \\
Accountability & 0.923 & 9 \\
Fairness & 0.690 & 8 \\
Student leadership & 0.717 & 4 \\
\hline
\end{tabular}

\section{Data collection and analysis}

During the main study, questionnaires were distributed to all public universities' 35 student leaders' chairmen and their 35 deputies by Research Assistants through drop and pick method. Data collected was coded and grouped based on their similarity and then tabulated. Descriptive statistics and multiple linear regression techniques were used to analyze data. Central tendency measures including mean and standard deviation were used to examine individual variables while correlation and regression analyses were 
used to establish relationships between the dependent and independent variables. Open-ended questions were analyzed using conceptual content analysis. The study used Statistical Package for Social Sciences (SPSS) V 22.0 for quantitative data analysis to generate statistics. Multiple regression analysis was used to determine the strength and direction of the variables and their effect as shown below:

$Y=\beta_{0}+\beta_{1} X_{1}+\beta_{2} X_{2}+\beta_{3} X_{3}+\beta_{4} X_{4}+\beta_{5} X_{5}+e$

Where, $Y=$ Student leadership $\quad \mathrm{e}=$ error term

$\mathrm{X}_{1}=$ Legitimacy and voice $\quad \beta_{0}=$ represents constant

$\mathrm{X}_{2}=$ Direction

$\beta_{12345}=$ are regression coefficients

$\mathrm{X}_{3}=$ Performance

$\mathrm{X}_{4}=$ Accountability

$\mathrm{X}_{5}=$ Fairness

\section{Ethical considerations}

Ethics in research is important to ensure consent is obtained from authorities before research is done and that respondents are appropriately appraised about research. An authorization permit was obtained from National Commission for Science, Technology, and Innovation (NACOSTI) which authorizes research in the country. Respondents on the other hand signed a predesigned consent form before the Research Assistants collected data from them. The structured questionnaires issued to the respondents also stated that they were under no obligation to take part in the study. The principle of anonymity was applied as is standard practice. This meant that, throughout the study including from researchers to reporting, the participant remained anonymous throughout.

\section{Results of the study}

At the end of data collection, a total of 65 questionnaires were collected giving a high response rate of 93\%. Demographic analysis indicates that $80 \%$ of the respondents were male while $20 \%$ were female showing that most respondents were male. Analysis by age indicates that majority $(83 \%)$ of the respondents were aged from 19-25 years while ages for the rest (17\%) ranged between 25 and 30 years. This implies that majority of the student leaders were young adults aged 25 years and below which is the most vibrant age in universities in Kenya. Further analysis done by level of study indicates that most (80\%) respondents were undergraduates while $20 \%$ were master students. Broadly these demographics demonstrate that student leaders in the study were predominantly male pursuing undergraduate degrees and generally in the early youth category aged between 19 and 25 years. 


\section{Descriptive statistics}

Statistics for mean and standard deviation were determined for all dimensions of principles of governance and student leadership using SPSS Version 22. The means which were above 2.5 indicate that the respondents judged the variable as important. Relatively low corresponding values of their standard deviation however show that there was less variation in this view. Table 2 presents the results of the descriptive statistics for all the variables.

Table 2: Descriptive Statistics

\begin{tabular}{ccc}
\hline Variable & Mean & Std. Dev. \\
\hline Legitimacy and voice & 3.63 & 0.903 \\
Direction & 3.67 & 1.05 \\
Performance & 3.93 & 0.86 \\
Accountability & 3.83 & 0.87 \\
Fairness & 3.80 & 0.79 \\
Student leadership & 3.71 & 0.70 \\
\hline
\end{tabular}

As can be seen in Table 2, the mean values for all the variables were above 3.6 while the highest standard deviation was 1.05 . These mean values are nearer the maximum Likert scale value of five (5) which demonstrates that respondents regarded these measures of principles of governance and student leadership as important in universities under study. From the standard deviation values, these views did not seem to vary much showing that the respondents' views were similar and consistent across all public universities studied.

\section{Model testing}

All the hypotheses for this study were tested using multiple linear regression analysis at $95 \%$ confidence interval. In determining significance levels, maximum p-value of 0.05 was used and single-tail test applied since all the hypotheses pointed to one direction. The results of the regression analysis for the overall model are shown in Table 3.

Table 3: Model Fitness

\begin{tabular}{ccccc}
\hline Model & $\mathrm{R}$ & $\mathrm{R}$ Square & Adjusted R Square & Std. Error of the Estimate \\
\hline 1 & $0.441 \mathrm{a}$ & 0.194 & 0.030 & 0.33713 \\
\multicolumn{2}{l}{ Predictors: (Constant), Fairness , Legitimacy, Accountability, Performance, Direction } \\
\hline
\end{tabular}

According to Table 3, the results of the fitness of model clearly show that the model was very weak. This is so because the coefficient of determination ( $\mathrm{R}$ square) is only $0.194 \%$. This model may thus be used to explain a paltry $19.4 \%$ of the variations in the student leadership. The model was further tested through analysis of the variance (ANOVA) and the results therefrom are given in Table 4. 
Table 4: Analysis of Variance

\begin{tabular}{cccccc}
\hline & Sum of Squares & d.f & Mean Square & F & Sig. \\
\hline Regression & 0.493 & 5 & 0.099 & .868 & .522 \\
Residual & 2.046 & 18 & 0.114 & & \\
Total & 2.539 & 23 & & & \\
\hline
\end{tabular}

Table 4 presents analysis of the variance (ANOVA) results. The results show that the overall model was statistically insignificant $(\mathrm{p}=0.522$ which is $>0.05)$ and very weak $(F=0.868)$. The regression coefficients for the individual variables are shown in Table 5.

Table 5: Regression of Coefficients

\begin{tabular}{cccccc}
\hline & \multicolumn{2}{c}{ Un standardized Coefficients } & Standardized Coefficients & T & Sig. \\
& $\mathrm{B}$ & Std. Error & Beta & & \\
\hline (Constant) & 5.024 & 1.614 & & -.113 & .006 \\
Legitimacy and voice & .029 & .197 & -.033 & -.149 & .883 \\
Direction & .262 & .213 & -.299 & -1.226 & .236 \\
Performance & .206 & .219 & -.214 & .942 & .035 \\
Accountability & .195 & .267 & .159 & .728 & .047 \\
Fairness & .042 & .301 & -.034 & -.139 & .891 \\
\hline
\end{tabular}

As Table 5 shows, the relationship between student leadership and legitimacy and voice, direction, and fairness respectively is respectively not significant. However performance and student leadership are positively and significantly related $(\mathrm{r}=0.206, \mathrm{p} \leq 0.035)$. Similarly, accountability and student leadership are positively and significantly related $(\mathrm{r}=0.195, \mathrm{p} \leq 0.047)$. Based on these results, the optimal model may be written as: $\mathrm{ESL}=5.024+0.206$ Perf +0.195 Acc.

Where: $\mathrm{ESL}=$ Effective student leadership; Perf =Performance; Acc. $=$ Accountability

\section{Results of hypothesis tests}

The first hypothesis, $\mathrm{H}_{01}$, stated that there is no significant relationship between legitimacy and voice principle and student leadership. Results in Table 5 show that the p-value is $0.883>0.05$. This indicates that the null hypothesis is not rejected and hence legitimacy and voice principle is not related to student leadership. Hypothesis $\mathrm{H}_{02}$ on the other hand stated that direction principle does not have a significant influence on student leadership. Results in Table 5 show that the p-value is $0.236>0.05$. This indicates that the null hypothesis was not rejected hence direction principle does not influence student leadership. Regarding hypothesis $\mathrm{H}_{03}$, the proposition was that the relationship between performance principle and student leadership is not significant. Results in Table 5 show that the p-value is $0.035<0.05$. This indicates that the null hypothesis was rejected hence performance principle is significantly related to student leadership. 
Concerning hypothesis $\mathrm{H}_{04}$, the postulation was that accountability principle has no significant impact on student leadership. Results in Table 5 show that the $\mathrm{p}$-value is $0.047<0.05$. This indicates that the null hypothesis was rejected and hence accountability principle significantly impacts on leadership. Lastly, hypothesis $\mathrm{H}_{05}$, assumed that there is no significant relationship between fairness principle and student leadership. Results in Table 5 show that the p-value is $0.891>0.05$. This indicates that the null hypothesis was not rejected hence fairness principle is not significantly related to student leadership.

\section{Discussion}

The main objective of this study was to establish the governance principles in the public universities' current student leadership in Kenya and recommend appropriate actions necessary to reduce student unrests. The study underscored the extent to which governance principles are necessary for students as a tool to ensure more informed participation in student and university affairs. In order to investigate this objective, a five item governance framework pioneered by UNDP (1997) was used. The hypothesis test results show that the relationship between the first principle, legitimacy and voice, was not significant. This suggests that, despite the respondents considering this principle as important (Mean=3.63; Std. Dev=0.903), it was not found among student leaders in public universities. The finding is consistent with Holdworth (2013). Essentially, the results imply that, when student leaders are articulating students' issues in various forums, including university Senate meetings, they are not guided by legitimacy and voice principle. In other words when making decisions, they tend to be guided by their own personal position rather than reasonable voice and consensus orientation. This makes decision-making process devoid of mediation necessary for opposing interests to arrive at a broad consensus on best interest for the university and student body.

The analysis further shows that the hypothesis predicting significant relationship between direction principle and student leadership was not significant. This means that much as this principle was regarded as important (mean=3.67; Std. Dev=1.05), it was non-existent among public university student leaders under study. This revelation is similar to that of Jaramilla and Lazo (2010). Basically, the implication is that the student leaders lack a strategic vision necessary to guide their leadership initiatives. Effectively, there is no clear broad roadmap hinged on long-term perspective and good governance for addressing student interests. The findings also show that performance was deemed an important issue for student leadership.

Performance principle is vital in achieving responsiveness when handling matters concerning university administration and the student body. 
Furthermore, effectiveness and efficiency are key issues especially owing to the fact that public universities' funding through the government is not adequate to meet all the administration and student needs. Although student leadership behaviour could be motivated by the quest to press for improved standards arising from inadequate funding from the government, the results show that the student leaders demonstrated some appreciation of responsiveness by trying to strike a balanced position of the institutions' processes. The results also indicate that the student leaders showed some level of effectiveness and efficiency in terms of appreciating that public universities try to make the best use of the inadequate government funding to meet the institutions' objectives. These results are consistent with Bosire, Chemnjor and Ngware (2008) and conform to the student leaders' perception which show that they regarded the principle of performance as very important (mean=3.93; Std. Dev=0.86).

Accountability is a crucial issue especially in leadership positions. The two tenets of this principle, transparency and flow of information, are essential tools in decision making process. The results of this study indicate that albeit to a small extent, accountability was found among student leaders in public universities. This implies that when making decisions, to some extent, student leaders are accountable to their constituency, the student body, as well as the institutional stakeholders including the university, the government, society, and surrounding communities. It also implies that there is some element of transparency among the student leaders hinged on free flow of information through honest and open articulation. These results are supported by a relatively high judgement of their importance (mean $=3.83$; Std. Dev=0.87) by respondents and are similar to those of Obondo (2000).

Finally, the results show that the hypothesized significant impact of fairness principle on student leadership was not significant contrary to the student leaders rating of this principle as important (mean=3.80; Std. Dev=0.79). This finding is consistent with Mitra (2006). This implies that student leaders are not guided by equity and rule of law in their deliberations. In other words, student leaders demonstrate absence of basic concept of balanced judgement. Effectively, when articulating student issues to the university administration, the leaders do not believe that these parties have equal opportunities and hence tend to overemphasize the student body's position. The student leaders are also perceived to ignore the rule of law. In this process, they fail to show appreciation and respect for legal frameworks. This may be demonstrated by the often violent forms of student unrests which normally culminate in violation of the rule of law through wanton destruction of property and sometimes loss of lives. 


\section{Conclusion}

This study's results show that out of five UNDP (1997) governance principles, only two existed among public university student leaders. These are governance principle of performance and that of accountability. Even though these were found among the student leaders, they were not very strong indicating low levels of impact in student leadership's actions. Performance principle is important in striking a fit between student leaders' responsiveness and the quest for effectiveness and efficiency demands. The levels were however relatively weak and hence may need reinforcement. On the other hand the principle of accountability which also returned weak but significant results is important in striking a balance between transparency and flow of information. Transparency is often demanded by students thus no wonder the results show they exhibit it while on the other hand flow of information is important to them to know what is going on.

The study however returned negative results for three governance principles of legitimacy and voice; direction; and fairness. This demonstrates that student leaders are usually not guided by these principles. In addition, they are also not guided by principle of direction hence lacking long-term vision for the students they represent. Finally, absence of fairness principle among the student leaders means that their deliberations are devoid of rule of law and equity. In conclusion, the study achieved its main objective and established the status of relationships of the five UNDP (1997) governance principles on student leadership in public universities.

This study was done against some limitations one of which is that data was only collected from the two top student leaders; these are chair and the deputy chair, while in essence other members of the student government may have some influence on the behavior of the two top student leaders. The study also did not use qualitative approach like focus group discussion (FGD) to collect data. FGDs are usually useful in stimulating discussions in studies of this nature which involve groups. Finally, the study was limited to public universities yet they are only half of the total university population in Kenya. However, these limitations notwithstanding, the results, findings, conclusion, and recommendations of the study are valid owing to the rigour of methodology and analytical models used in the study.

\section{Recommendations}

Based on the findings which show weak or lack of aspects of principles of governance among student leaders in public universities, this study recommends that: principles of governance should be introduced in all undergraduate level academic programmes at all public universities. This is because it is only appropriate to impart skills of good governance to students early in their university education. However, their introduction should be 
done in a manner that is relevant and adds value to a student's academic interest. One approach would be to contextualize the curriculum based on the student's area of specialization. Further, there should be emphasis on practical application of the principles of governance learned during the students' university life. Also the students should be taught leadership as a mandatory subject regardless of their area of study. Teaching leadership concepts will benefit the students by improving their appreciation of the work of a leader from a personal perspective. Furthermore, all the current crop of student leaders in public universities should be trained on governance principles and leadership concepts. This will enable them acquire requisite knowledge and skills necessary to effectively contribute in university Senate meetings and articulate student matters from a balanced position. Finally, the study recommends that further research be done focusing on private universities since the government has recently started placing students in these universities and soon they may be faced with similar challenges as public universities. Future studies may also adopt phenomenological philosophy and use qualitative methods of data collection and analysis to facilitate establishment of qualitative and social aspects of the issues surrounding governance and student leadership. Lastly, other studies may use longitudinal design to allow time series analysis of factors causing student unrests.

\section{References:}

1. Adeyemi, T.O. (2009). Causes, consequences and control of students' crises in public and private universities in Nigeria. Educational Research and Review Vol. 4 (4), pp. 156-163, ISSN 1990-3839 Academic Journals. Available online at http://www.academicjournals.org/ERR

2. Block, P. (2013). Stewardship: Choosing Service over Self-Interest. BK Business. Australia.

3. Bosire, J., Chemnjor, C., and Ngware, M. (2008). Students' Leadership in Selected Public Universities in Kenya: Disfranchised Pressure Groups or an Integral Component in University Management? An International Multidisciplinary Journal, Ethiopia Vol. 2 (3), 195-221, ISSN 1994-9057 (Print)

4. Cohen, L., Manion, L. \& Morrison, K. (2004). Research methods in Education, 5th Edition Routledge - Falmer: London.

5. Commission for University Education (2017). Accredited Universities in Kenya Retrieved from http://www.cue.or.ke/images/phocadownload/Accreditted_Universiti es_March_2017. df on 30/10/2017 
6. Cook-Sather, A. (2006). Sound, presence, and power: 'Student voice' in educational research and reform. Curriculum Inquiry, 36(4), 359-390. "Charting the Directions of Code of Corporate Governance, Final Report and Code of Corporate Governance Retrieved from http://www.mof.gov.sg/. ISSN 10353552

7. Delves D. and Patrick.B (2010) Agency Theory Summary http://www.delvesgroup.com/wpcontent/ uploads/2010/08/AgencyTheory Summary_Delves-Patrick.pdf.

8. Drafke, M. W. \& Kossen, S. (2002). The human side of organization (8th Edition Upper Saddle River, NJ: Prentice Hall.th

9. Eckersley, R., Cahill, H., Wierenga, A., \& Wyn, J. (2007). Generations in Dialogue about the Future: The hopes and fears of young Australians. Melbourne: Australia 21 Limited and the Australian Youth Research Centre.

10. Falua BT (2004) "Management of students crisis in secondary schools in Ado-Ekiti Local Government Area of Ekiti State" Unpublished Med Thesis, University of Ado Ekiti. pp.63-72.

11. Fayol, H. (1949). General Industrial Management: New York: McMillan.

12. Fieldings, M. (2012). Student voice: patterns of partnership and the demands of deep democracy. Connect, San Franscisco197, 10-15.

13. Graham, J., Amos, B., and Plumptre, T. (2003). Governance principles for protected areas in the 21st century. Prepared for The Fifth World Parks Congress Durban, South Africa

14. Gvirtz, S., \& Minvielle, L. (2009). 'Democratic Schools in Latin America? Lessons Learned from the Experiences in Nicaragua and Brazil', in P. Woods and G. Woods (eds) Alternative

Education for the 21st Century: Philosophies, Approaches, Visions, npp. 3148 London: Palgrave.

15. Gudo, C. (2014). Kenya financing higher education in Kenya: Public-Private partnership approach. International Journal of Educational Policy Research and Review, 1(1), 001005.

16. Holdsworth R. (2013). 'Student participation in school leadership', Leadership: The Centre of Learning. 20(2), 26-27. Retrieved from http://uar.sagepub.com ISSN 02357363

17. Jaramilla, A., \& Lazo, L. (2010). Governance Practices By The Student Government $O f \quad$ The University of Northern Philippines: A Paradigm Shift In The Administrative Supervision Of And Support For Student Development Programs. University of Northern Philippines) 
18. Jensen, M.C., \& Meckling, W.H. (1976). Theory of the firm: Managerial behavior, agency costs and ownership structure. Journal of Financial Economics (October), 3(4):305-360.

19. Kathryn, M., Zuckweiler, Kirsten, M., Rosacker, A., \& Suzanne, K. (2016) "Business Students' Perceptions of Corporate Governance Best Practices", Corporate Governance, 16: 2, 361376

20. Kivati, G. (2017). The Role of Kenya's Formal Higher Education in Sustainable Development Within the Context of Globalization. W. Leal Filho et al. (eds.), Handbook of Theory and Practice of Sustainable Development in Higher Education, World Sustainability Series, DOI 10.1007/978-3-319-47889-0_2. Springer International Publishing AG 2017.

21. Kenya Law Reforms (2012). Laws of Kenya - Universities Act Chapter 210B. National Council for Law Reporting with the Authority of the Attorney-General, www.kenyalaw.org

22. Kiai, M (N.D). Haven of oppression: A report on the University of Nairobi and Academic Freedom in Kenya. Retrieved from resource.knhrc.ke on 27.10.2017.

23. Kiboiy, K.L. (2013). The dynamics of unrests in Kenya's higher education: The case of Moi University. Unpublished Ph.D Thesis, Department of Education Management and Policy Studies, University of Pretoria, S.A.

24. Knight, J. (2008). Internationalization of Higher Education: Complexities and Realities, inTeffera, D. and Knight, J (Ed) (2008): Higher Education in Africa: The International Dimension. Center for International Higher Education, Boston College and Association of African Universities, Accra, Ghana.

25. Komives, S. R., Lucas, N. \& McMahon, T. R. (1998). Exploring Leadership for College Students who want to make a difference. San Francisco: Jossey-Bass Publishers. Retrieve from http://www.undp.org/hdr2003/indicator/cty_f_NIC. ISSN 0146-3934

26. Magolda, P., \& Ebben, K. (2006. College student involvement and mobilization: An ethnographic study of a Christian student organization. Journal of College Student Development, 47, 281298. https://muse.jhu.edu/article/ ISSN 0197832

27. Mawanza, W (2014). "The Mordern Corporation": A Theoretical Review Of The Modern Corporation In Zimbabwe And The Use Of Share Option Schemes As A Way OfReducing The Agency Problem In Stockmarket Listed Companies. European Journal of Business and Social Sciences, Vol. 3, No.3 , pp 28-38, June 2014. 
P.P. 28 -38 URL: http://www.ejbss.com/recent.aspx ISSN: 2235 $-767 \mathrm{X}$

28. May, W. P. (2009). "Student Governance: A Qualitative Study of Leadership in a Student Government Association." Dissertation, Georgia State University. http://scholarworks.gsu.edu/eps_diss/36

29. Mbirithi, M.D. (2013). Management Challenges Facing Kenya's Public Universities and Implications for the Quality of Education. Unpublished $\mathrm{PhD}$ Thesis, Kenyatta University, Kenya

30. Materu, P. (2007). Higher education quality assurance in SubSaharan Africa: Status, challenges, opportunities, and promising practices (World Bank Working Paper No. 124). Washington, DC: World Bank.

31. McInerney, P. (2009). Toward a Critical Pedagogy of Engagement for Alienated Youth: Insights from Freire and School-Based Research. Critical Studies in Education, 50(1), 23-35.

32. Mitnick, B. M., (1973). Fiduciary Rationality and Public Policy: The Theory of Agency and Some Consequences. Paper presented at the 1973 Annual Meeting of the American Political Science Association, New Orleans, LA. In Proceedings of the APSA, 1973 (formerly available from Xerox University Microfilms and, later, UMI Serials).

33. Mitra, D.L. (2006). Increasing student voice and moving toward youth leadership. The Prevention Researcher, Journal of Education, 13(1), 7-10. http://www.eboardsecure.dcsdk12.org ISSN 01744006

34. Mwiria, K., \& Ng'ethe, N. (2006). Public University Reform in Kenya: Mapping the Key Changes of the Last Decade, Nairobi: East Africa Educational Publishers.

35. Nagel, J. (1987). Participation. Englewood Cliffs, NJ: Prentice Hall.

36. Munene, I.I. (2012) Our University: Ethnicity, Higher Education and the Quest for State Legitimacy in Kenya. Higher Education Policy, Volume 26, Issue 1, pp 4363.

37. Obondo, A. (2000). Politics of Participatory Decision-Making in Campus Governance. Faculty of Education. University of Nairobi. Kenya

38. Ojo JD (1995). Students' unrest in Nigerian universities: A legal and historical approach, Lagos: Spectrum Books Ltd. pp. 34-36.

39. Oketch, M. (2004). The emergence of private university education in Kenya: trends, prospects, and challenges. International Journal of Education Development, 24, 119-136. Sergiovanni, T. (2000). The Lifeworld of Leadership. Jossey-Bass, London 
40. Sifuna, D. N. (2010). Some reflections on the expansion and quality of higher education in public universities in Kenya. Research in Post-Compulsory Education, 15(4), 415-425.

41. Siringi, E.M \& Letting, N.K. (2016). Appointment of ViceChancellors in Public Universities in Kenya: The Nexus between Ethnicity and University Employment. International Journal of Management and Leadership Studies. Vol. 1 (1) pp. 1-17

42. Toshalis, E., \& Nakkula, M. (2012). Motivation, engagement and student voice. Students at the Center. Retrieved from http://www.creativecommons.org/licenses/by/3.0/ ISSN 0157064

43. UNDP (1997). "Governance and Sustainable Human Development. Retrieved from www.mirror.undp.org/magnet/policy ISSN 782648

44. UNESCO (2017). Concept of Governance. Retrieved from http://www.unesco.org/new/en/education/themes/strengtheningeducation systems/quality-framework/technical-notes/conceptof-governance/ on 30/10/2017

45. University World News (2014). Student numbers soar by 35\%, university funding lags. Retrieved from http://www.universityworldnews.com/article.php?story=2014050807 5050866 on 28.10 .2017

46. Walsh, L. (2012). More mixed messages about youth participation. Journal of Youth Studies Australia .31(2).

47. Yirdaw, A. (2016). Quality of Education in Private Higher Institutions in Ethiopia: The Role of Governance. Sage Open Publishers, Fielding Graduate University, Santa Barbara, CA, USA.

48. Yukl, G. (2009). Leadership in Organizations. Upper Saddle River, NJ: Prentice Hall. 